\title{
POTENSI KERUSAKAN TERUMBU KARANG PADA KEGIATAN WISATA SNORKELING DI DESTINASI WISATA TAMAN NASIONAL KARIMUNJAWA
}

\section{POTENTIAL DAMAGE TO CORAL REEF ON SNORKELING ACTIVITIES IN KARIMUNJAWA NATIONAL PARK TOURISM DESTINATION}

\author{
Dhanar Syahrizal Akhmad $^{1 *}$, Supriharyono², dan Pujiono Wahyu Purnomo \\ ${ }^{1}$ Program Pasca Sarjana, Manajemen Sumberdaya Pantai, FPIK-UNDIP, Semarang \\ ${ }^{2}$ Staf Pengajar Manajemen Sumberdaya Pantai, FPIK-UNDIP, Semarang \\ *E-mail: dhanarsyahrizal@mail.com
}

\begin{abstract}
Snorkeling tours in Karimunjawa National Park are one of the fastest growing tourism sectors today in Karimunjawa. Increasing snorkeling tourists can cause ecological pressure on coral reefs at snorkeling sites. This study aims to determine the direct contact of snorkeling tourists and tour operators against damage to coral reefs, this research was conducted by following tour operators. The most frequent physical contact carried out by tourists is kneel stand on the reef, while for tour operators is the mooring of boats, feeding of fish, and not reprimanding tourists. The physical contact value at the Ujung Bintang spot is 0.029 individuals per minute, the physical contact value at Maer spot is 0.063 individuals per minute, and the physical contact value on the Karang Sendok spot is 0.038 individuals per minute.
\end{abstract}

Keywords: tourism activity, snorkeler behavior, coral reef, karimunjawa

\begin{abstract}
ABSTRAK
Wisata snorkeling di Taman Nasional Karimunjawa merupakan salah satu sektor wisata yang paling pesat perkembanganya saat ini di Karimunjawa. Semakin meningkatnya wisatawan snorkeling dapat menimbulkan tekanan ekologi terumbu karang pada lokasi snorkeling. Penelitian ini bertujuan untuk menentukan kontak langsung wisatawan snorkeling dan operator wisata terhadap kerusakan terumbu karang, penelitian ini dilakukan dengan mengikuti operator wisata. Kontak fisik yang paling sering dilakukan oleh wisatawan adalah sit stand kneel pada karang, sedangkan untuk operator wisata adalah penambatan perahu, pemberian pakan pada ikan, serta tidak menegur wisatawan. Nilai kontak fisik pada spot Ujung Bintang 0,029 individu per menit, nilai kontak fisik pada spot Maer 0,063 individu per menit, nilai kontak fisik pada spot Karang Sendok 0,038 individu per menit.
\end{abstract}

Kata kunci: aktifitas wisatawan, perilaku snorkeler, terumbu karang, karimunjawa

\section{PENDAHULUAN}

Zona pemanfaatan wisata bahari di Taman Nasional Karimunjawa memberikan harapan bagi masyarakat guna meningkatkan per-ekonomian serta menciptakan lapangan pekerjaan baru di bidang industri pariwisata. Perkembangan Kepulauan Karimunjawa sebagai tujuan wisata telah di dorong oleh pasar domestik maupun regrional, serta di promosikan sebagai salah satu spot untuk menyelam maupun snorkeling dengan masyarakat ikut berperan serta sebagai penyedia jasa operator wisata, tour guide, maupun akomodasi (Campbell et al., 2013). Kunjungan wisata yang meningkat dari tahun ke tahun (BPS, 2014; BPS, 2015; BPS, 2016) menimbulkan kekhawatiran mengenai keberlangsungan kegiatan wisata, khususnya wisata snorkeling yang tidak terkendali bagi keberlanjutan daerah wisata maupun ekologi dari terumbu karang (BTNK, 2012). Terumbu karang merupakan salah satu ekosistem laut paling terancam akibat perubahan alam maupun antropogenik, baik berskala global maupun lokal (Lasagna et al., 
2014). Seiring berjalannya kegiatan wisatsa yang dilakukan dengan pemanfaatan kawasan terumbu karang untuk kegiatan wisata, maka terumbu karang akan selalu mengalami tekanan dan mengarah pada kerusakan (Roche et al., 2016). Terumbu karang yang tedegradasi erat kaitannya dengan keanekaragaman yang ada, bahkan dapat merubah spesies yang dominan dari terumbu karang tersebut, sebagai contoh adalah perubahan dimana terumbu yang sudah mati akan di tumbuhi oleh alga, selain adanya perubahan spesies dominan, terumbu karang yang terdegradasi juga berdampak pada faktor daya tarik fisik, ikan karang, dan kemampuan untuk mempertahankan strukturnya sebagai breakwater, dampak sosial dan ekonomi juga akan berkurang (Done, 1992; Fava et al., 2009).

Taman Nasinoal Karimunjawa merupakan perairan yang produktif dengan tutupan terumbu karang keras (hard coral), selain faktor alam tutupan terumbu karang juga di pengaruhi oleh tingkat pemanfaatan yang tinggi (Sulisyati et al., 2014).

Wisata snorkeling merupakan salah satu kegiatan wisata yang rentan terhadap kerusakan terumbu karang (Hawkins et al., 1999; Webler and Jakubowski, 2016), namun wisata snorkeling sebetulnya merupakan kegiatan wisata berdampak rendah bagi lingkungan dimana kegiatan snorkeling bisa dilakukan tanpa bersentuhan langsung dengan terumbu (Marion and Rogers, 1994). Perilaku wisatawan dalam melakukan kegiatan wisata di daerah terumbu karang tidak sepenuhnya merusak, bahkan banyak wisatawan juga telah sadar akan dampak yang ditumbulkan dan berusaha menghindari kerusakan karang (Webler and Jakubowski, 2016).

Kekhawatiran akan melebihi daya dukung lingkungan akan menjadi semakin rentan apabila kegiatan wisata yang dikembangkan terjadi di pulau-pulau kecil dimana sumber daya alam yang terbatas dan operator wisata akan selalu memenuhi kebutuhan untuk para wisatawan dalam menjalankan bisnis industri wisata (Buckley, 1996; Weng, 2009). Kegiatan snorkeling menjadi salah satu dari berbagai ancaman yang terjadi pada terumbu karang apabila tidak dilakukan dengan benar (Allison, 1996).

Penelitian ini bertujuan untuk menentukan kontak langsung wisatawan snorkeling dan operator wisata terhadap kerusakan terumbu karang, penelitian ini dilakukan dengan mengikuti operator wisata.

\section{METODE PENELITIAN}

Lokasi pengamatan dilakukan pada lokasi wisata snorkeling yang sering dikunjungi dengan turut serta dalam kegiatan wisata yang dilakukan oleh operator wisata pada Zona Pemanfaatan Wisata Bahari sesuai dengan SK Ditjen PHKA No: SK.28/IV/Set3/2012 pada spot Ujung Bintang dan spot Maer yang berlokasi di P. Menjangan Kecil, spot Karang Sendok yang berlokasi di P. Menjangan Besar (Gambar 1).

Pengamatan wisatawan snorkeling dilakukan dengan mengamati perilaku yang berpotensi merusak (kontak langsung) terhadap terumbu karang yang dilakukan (Tabel 1). Pengamatan dilakukan ketika wisatawan mulai memasuki perairan dan berakhir apabila wisatawan keluar dari perairan. Jumlah pengunjung dan lamanya waktu yang diberikan kepada wisatawan sepenuhnya berasal dari operator wisata. Kerentanan terumbu karang akibat kontak fisik wisatawan dianalisis dengan menggunakan rumus:

$$
\text { Di. } \mathrm{pm}=\left(\sum \mathrm{Nr} / \mathrm{No}\right) / \mathrm{Tt}
$$

Keterangan : Di.pm : Kerusakan Individu per menit, $\mathrm{Nr}$ : Perilaku yang mengancam, No : Jumlah wisatawan per trip, dan Tt : Waktu yang disediakan operator wisata. 


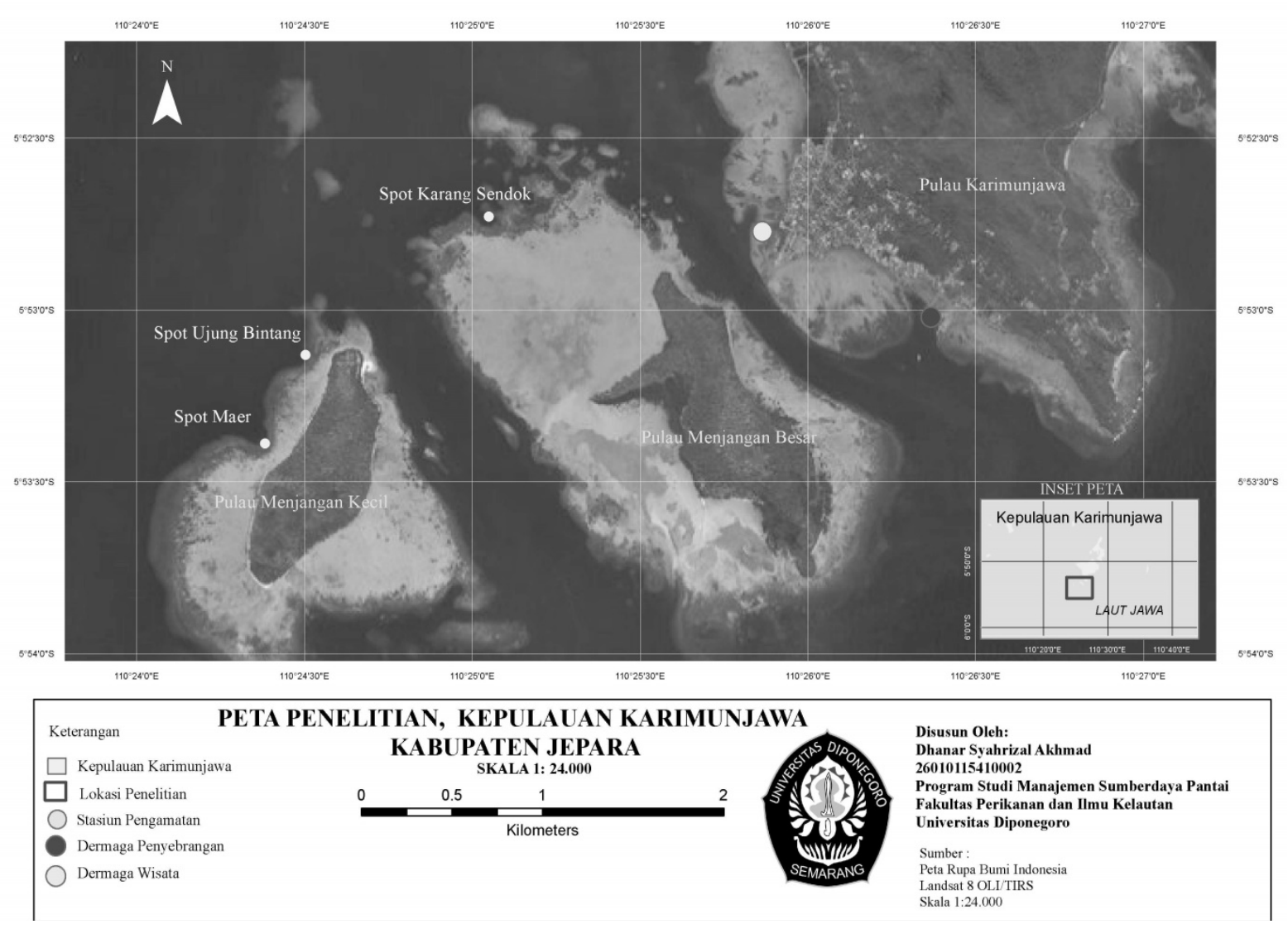

Gambar 1. Peta lokasi penelitian.

Tabel 1. Potensi kontak fisik wisatawan terhadap terumbu karang.

\begin{tabular}{cll}
\hline No & Perilaku yang mengancam & \multicolumn{1}{c}{ Keterangan } \\
\hline 1 & Fins kick & Fins yang terkena karang \\
2 & Sit, stand, kneel & Duduk, berdiri, berlutut pada karang \\
3 & Siltting & Membuat sedimen teraduk yang berpotensi menutup \\
4 & Hand touch & karang \\
5 & Pick up marine life & Menyentuh karang \\
6 & Harass marine life & Mengambil biota \\
7 & Collect objects or animals & Memungut dan mengoleksi benda-benda atau hewan \\
8 & Body brush & Bagian tubuh yang tidak sengaja terkena karang \\
\hline
\end{tabular}

Sumber: Webler and Jakubowski, (2016).

\section{HASIL DAN PEMBAHASAN}

\subsection{Kontak Fisik Wisatawan}

Hasil pengamatan dari 50 orang wisatawan, 8 wisatawan pada spot Ujung Bintang dengan waktu kegiatan 30 menit, 21 wisatawan pada spot Maer dengan waktu kegiatan 30 menit dan 21 wisatawan pada spot Karang Sendok dengan waktu kegiatan 40 menit. Nilai kontak fisik wisatawan tertinggi terdapat pada spot Maer sebesar 0,063 individu per menit, Karang Sendok 0,038 individu per menit, dan terendah pada spot Ujung Bintang 0,029 individu per menit (gambar 2). 


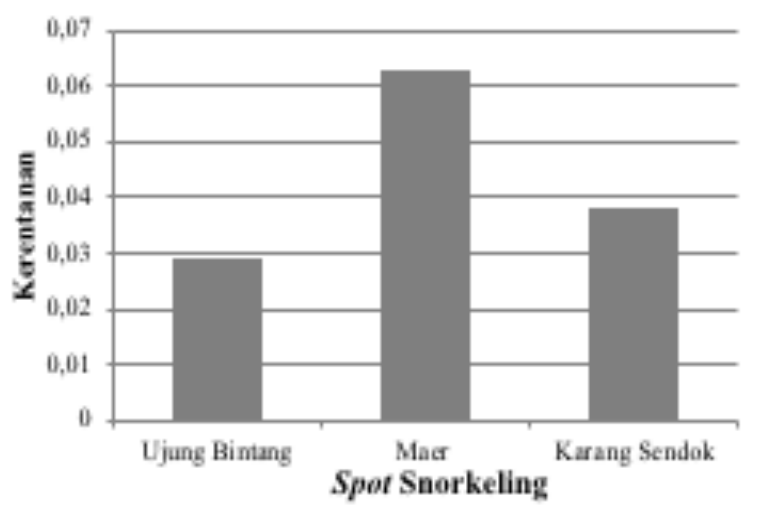

Gambar 2. Nilai kontak fisik wisatawan.

Kontak fisik wisatawan tertinggi disebabkan oleh duduk-berdiri-berlutut (sit stand kneel) pada koloni karang, kejadian ini terjadi karena wisatawan selalu berusaha berdiri pada karang yang dapat dijangkau oleh fins selama snorkeling. Harass marine life yang dilakukan wisatawan pada ketiga spot wisata di sebabkan karena wisatawan berusaha memegang ikan yang berada disekitar wisatawan, dimana operator wisata memfasilitasi dengan menyediakan makanan ikan berupa roti untuk menarik ikan (gambar $3)$.

Nilai kontak fisik pada spot Ujung Bintang 0,029 individu per menit, terdapat 4 kejadian untuk kategori sit stand kneel, dimana wisatawan berusaha berdiri pada beberapa koloni terumbu yang dapat dijangkau oleh fins, serta 3 kejadian untuk harass marine life dikarenakan wisatawan berusaha berfoto bersama ikan dengan pemberian pakan ikan oleh operator wisata. Kedalaman terumbu karang pada spot Ujung Bintang sebagian besar tidak dapat dijangkau wisatawan, namun beberapa koloni karang yang masih dapat dijangkau wisatawan selalu dijadikan pijakan oleh wisatawan (gambar 4). Pada spot ini terdapat kerusakan koloni karang dengan permukaan koloni yang terkikis.

Nilai kontak fisik pada spot Maer tertinggi dibandingkan dengan spot yang lain, dengan nilai 0,063 individu per menit, 36 kejadian untuk kategori sit stand kneel, 2 kejadian untuk harass marine life, dan 1 kejadian untuk hand touch dan fins kick (gambar 3). Tingginya kontak fisik yang terjadi pada spot Maer dikarenakan kedalaman terumbu karang yang sebagian besar dapat dijangkau oleh fins wisatawan. Kerusakan koloni yang terjadi pada spot Maer berupa kematian parsial koloni, koloni karang yang terkikis pada lifeform digitate, encrusting dan kematian parsial pada karang massive (gambar 5). Koloni terumbu yang dangkal pada spot ini dijadikan tempat untuk berpijak dan duduk oleh wisatawan serta menjadi sarana untuk foto bagi wisatawan.

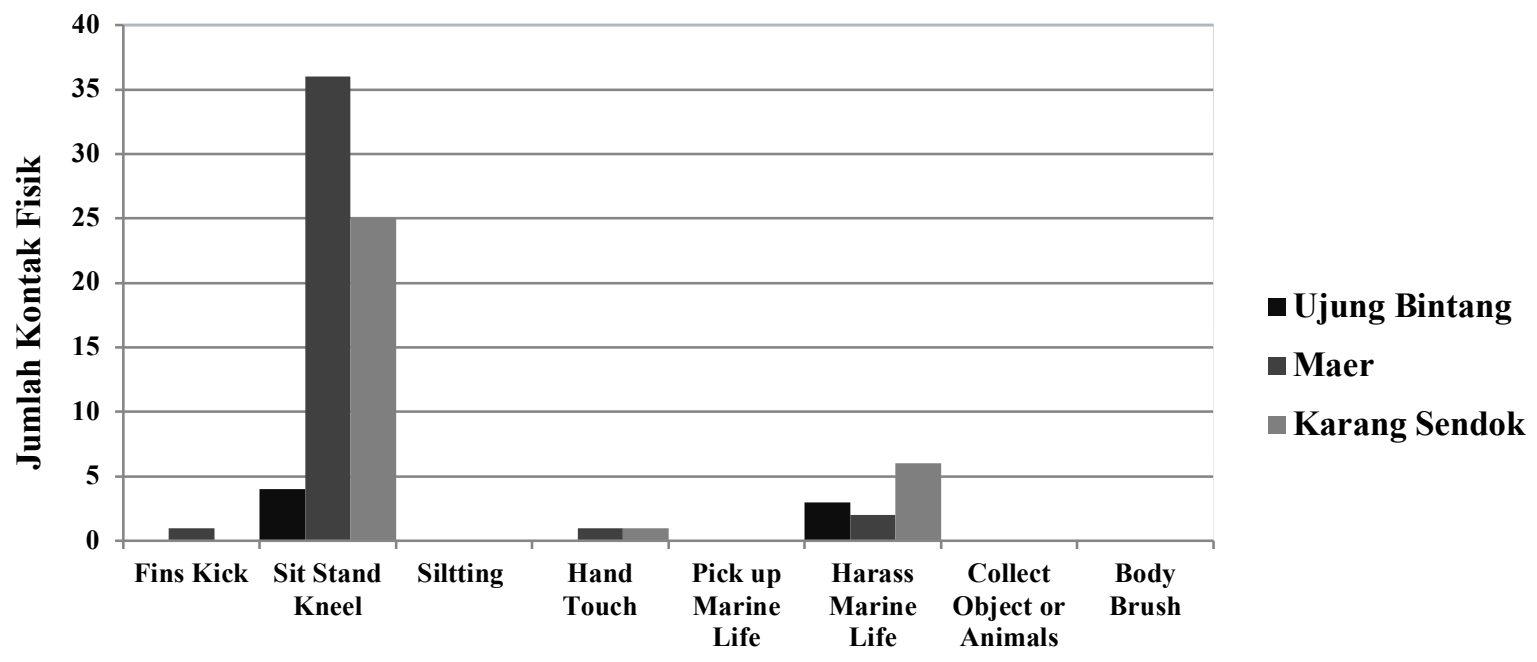

Kontak Fisik Wisatawan

Gambar 3. Kontak fisik wisatawan terhadap terumbu karang. 


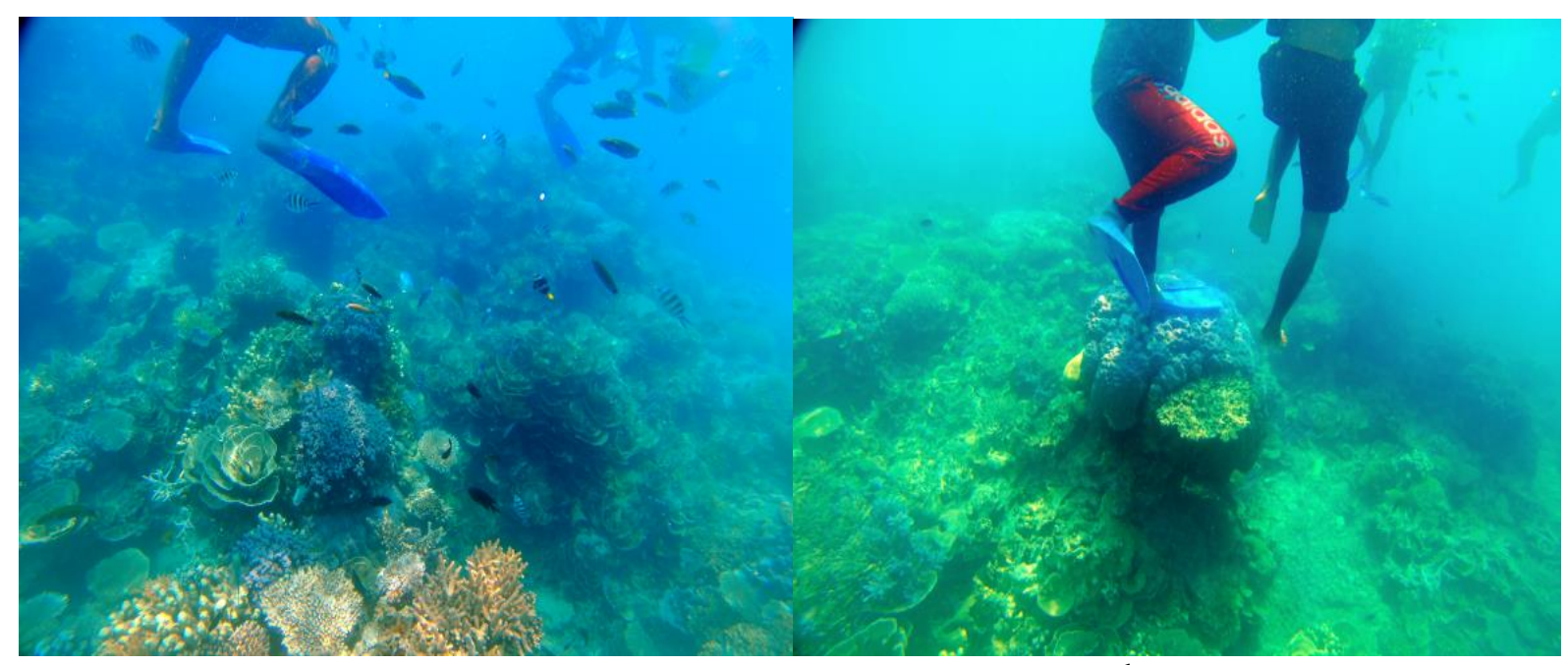

a

$\mathrm{b}$

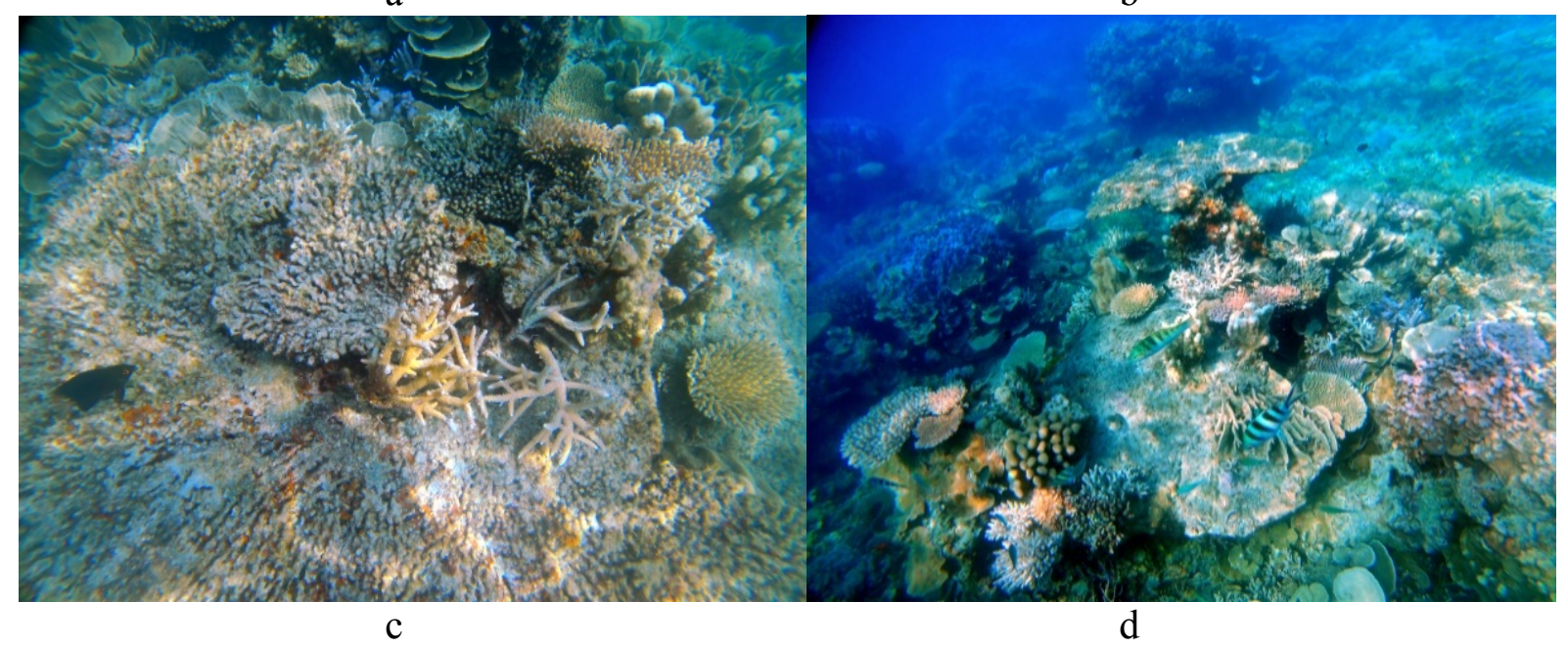

Gambar 4. Spot Ujung Bintang. Kondisi Terumbu yang tidak terjangkau fins wisatawan (a), Karang yang dijadikan pijakan (b), Kondisi permukaan koloni karang dengan permukaaan terkikis yang diduga akibat akumulasi gesekan dari fins wisatawan (c), Kondisi terumbu karang pada spot Ujung Bintang (d).

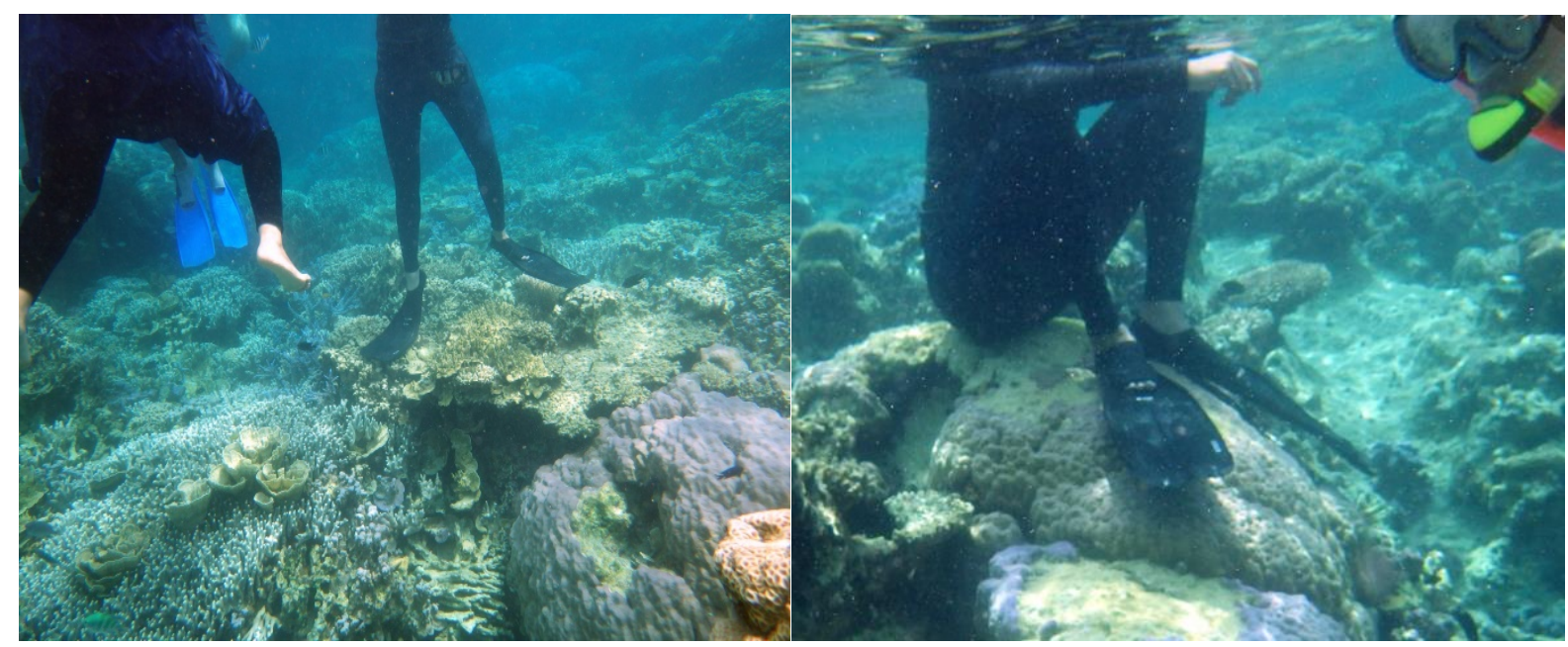

a 


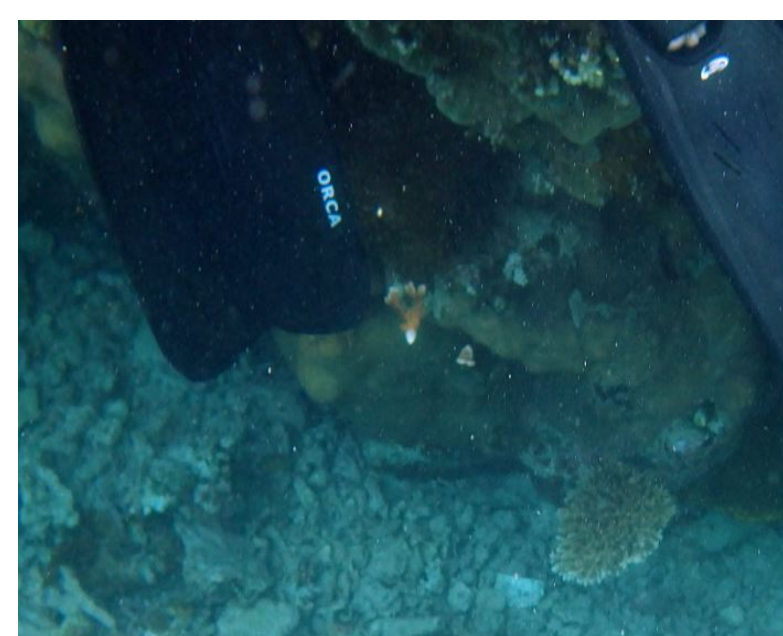

C

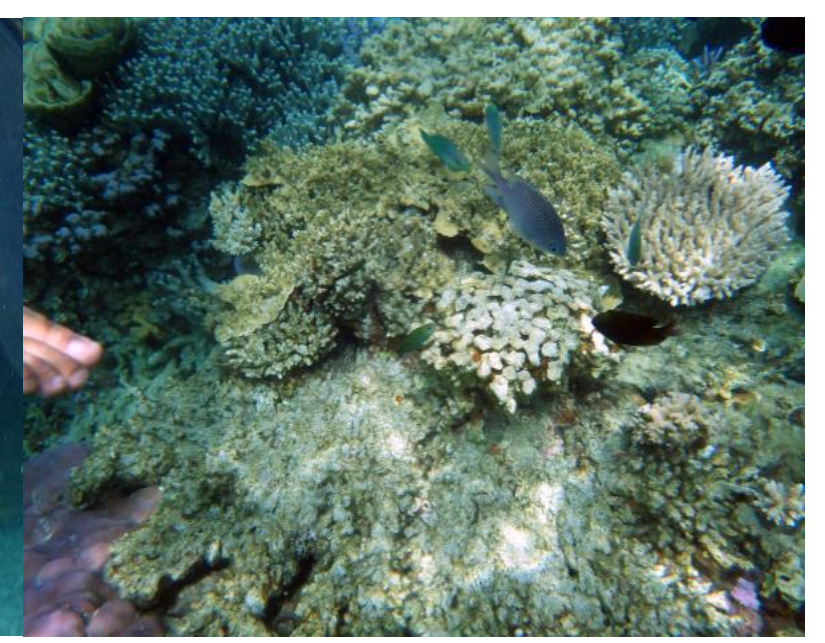

d

Gambar 5. Spot Maer. Wisatawan berdiri di terumbu karang yang dangkal (a), Wisatawan duduk di koloni karang massive yang mengalami kematian parsial (b), Cabang karang yang baru saja patah akibat terkena fins wisatawan (c), Kondisi koloni karang pada gambar "a"dengan permukaaan terkikis yang diduga akibat akumulasi gesekan dari fins wisatawan (d).

Kontak fisik yang menjadi perhatian pada spot Karang Sendok adalah harass marine life dimana operator wisata memperlihatkan soft coral dan clown fish sebagai daya tarik bagi wisatawan (gambar 6). Spot Karang Sendok mempunyai kedalaman terumbu yang sebagian besar tidak dapat dijangkau oleh fins wisatawan, namun beberapa terumbu karang yang dapat dijangkau oleh fins wisatawan selalu dijadikan pijakan oleh wisatawan untuk berdiri. Nilai kontak fisik pada spot Karang Sendok 0,038 individu per menit, dimana terdapat 25 kejadian untuk kategori sit stand kneel, 6 kejadian untuk harass marine life dan 1 kejadian untuk hand touch pada karang.

Panjangnya jangkauan kaki wisatawan dengan penggunaan fins baik secara tidak sengaja maupun sengaja dapat menyentuh terumbu, serta sedimen yang teraduk dapat menutupi dan mengubur terumbu karang (Chabanet et al., 2005), sedimen yang teraduk juga dapat mengganggu pertumbuhan dan reproduksi karang (Neil, 1990).

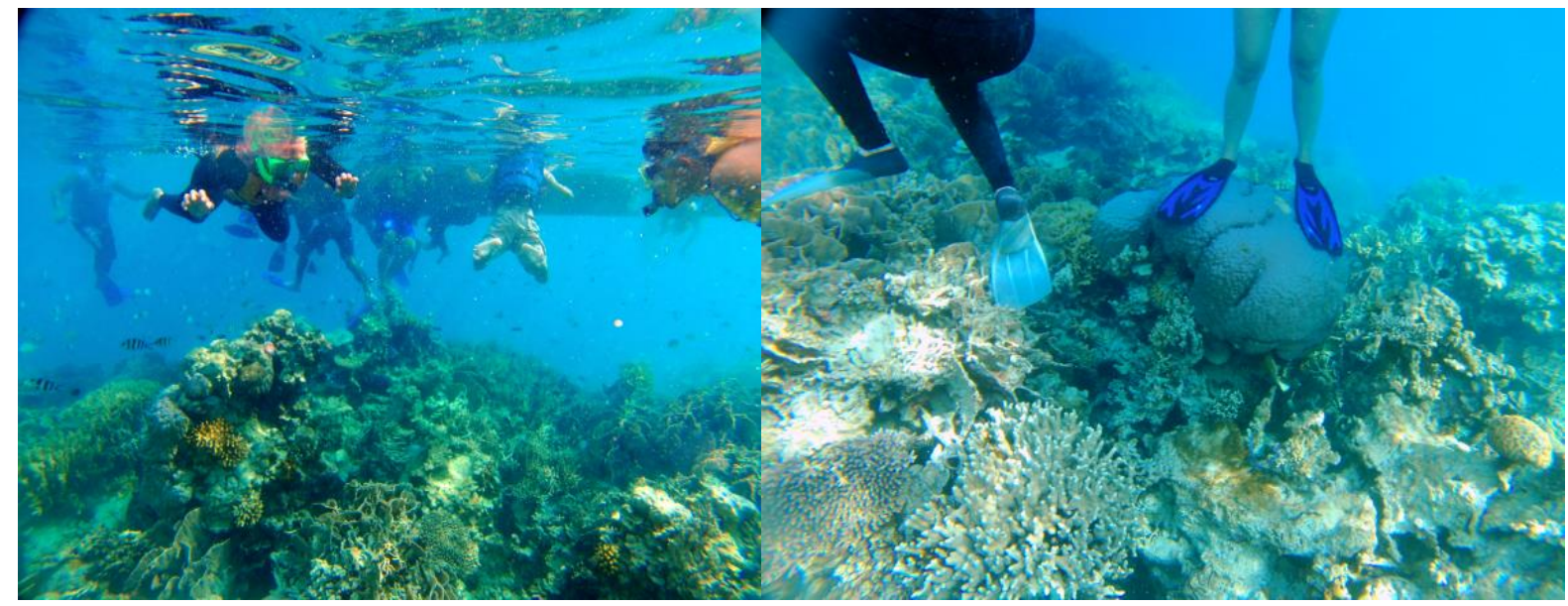

a b 


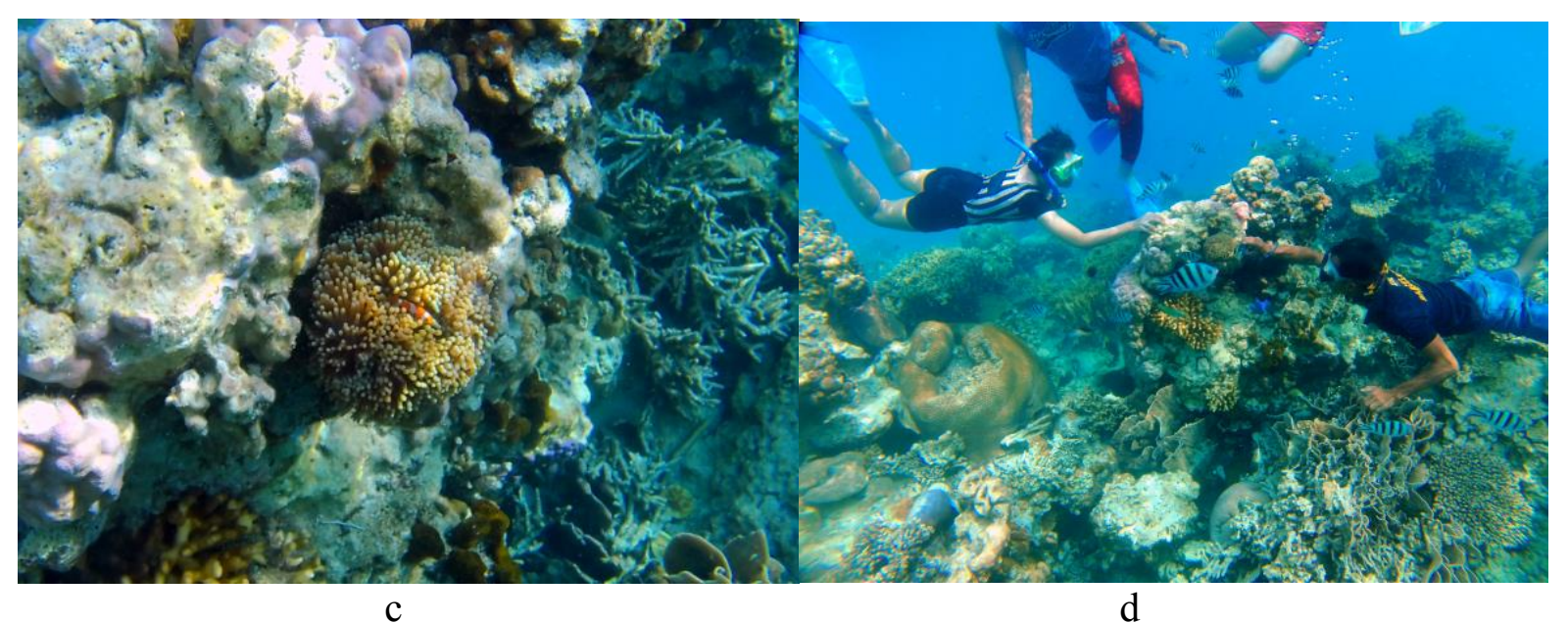

Gambar 6. Spot Karang Sendok. Terumbu sebagian besar tidak terjangkau oleh fins wisatawan (a), Wisatawan berusaha berdiri pada karang yang dijadikan pijakan (b), Clown fish dan soft coral sebagai daya tarik (c), Kegiatan foto bersama clown fish (d).

Selain fins, para wisatawan juga dapat merusak karang melalui peralatan yang dipakai, memegang, duduk, berdiri dan menginjak karang (Prior et al., 1995; Rouphael and Inglis, 2001), perilaku-perilaku tersebut biasanya sering dilakukan oleh wisatawan pemula (Chabanet et al., 2005; Webler and Jakubowski, 2016). Kontak fisik yang ditimbulkan wisatawan mempunyai dampak yang berbeda pada lifeform karang yang berbeda (Kay and Liddle, 1989). Polip karang dengan life form massive dalam menerima kerusakan merupakan secara kumulatif, dimana persentase kerusakan bergantung pada jumlah gesekan yang diterima, sedangkan polip karang pada lifeform branching bergantung dari kekuatan yang diterima secara seketika, namun jika dari keseluruhan koloni dipertimbangkan, maka kerusakan pada lifeorm branching dapat bersifat kumulatif dari banyaknya jumlah cabang yang patah (Liddle and Kay, 1987).

Kerusakan terumbu karang pada ketiga spot wisata berupa kematian koloni secara parsial, permukaan koloni karang yang terkikis, kerusakan tersebut terjadi pada life form karang massive, digitate, encrusting, serta cabang karang yang patah (gambar 4c; gambar 5b,5c,5d; gambar 6c). Kerusakan koloni yang terjadi pada ketiga spot wisata seperti koloni karang yang mengalami kematian secara parsial dan koloni yang terkikis/abrasi banyak ditemukan di daerah wisata (Hawkins and Roberts, 1992; Tratalos and Austin, 2001). Koloni karang dengan permukaan yang terkikis/abrasi cenderung dapat menyebabkan invasi dari patogen dan meningkatkan mortalitas (Hawkins and Roberts, 1992; Liddle and Kay, 1987), sedangkan banyaknya kematian parsial koloni karang di suatu terumbu, dapat mewakili kondisi dari kesehatan terumbu karang terhadap stress yang tinggi, serta dapat memberi gambaran proses perubahan dinamika pada karang (Dikou and van Woesik, 2006).

\subsection{Kontak Fisik Operator Wisata}

Operator wisata dalam penyelenggaraan kegiatan wisata snorkeling di Taman Nasional Karimunjawa sudah sesuai dengan aspek legal mengenai peruntukan spot wisata di Taman Nasional Karimunjawa berdasarkan Keputusan Direktorat Jenderal PHKA No: SK.28/IV/Set-3/2012. Operator wisata dalam penyelenggaraan kegiatan wisata snorkeling telah memberikan briefing 
mengenai keselamatan, kecakapan instruktur dan pengawasan wisatawan pada kolom air, serta penambatan perahu pada tepi terumbu (reef slope). Dari hasil pengamatan terhadap 2 perahu dengan 7 orang operator wisata, perahu untuk kegiatan wisata biasanya diisi 10 - 20 wisatawan dengan awak perahu minimal 3 orang dengan pembagian 1 orang mengemudikan perahu dan 2 orang mengawasi wisatawan di perairan. Operator pada spot snorkeling Ujung Bintang dilakukan oleh 3 orang operator, sedangkan spot Maer dan spot Karang Sendok dilakukan oleh 4 orang operator yang sama. Hal ini dikarenakan operator wisata pada tour yang dilakukan menerapkan sistem Path Model Circular Loop dimana wisatawan diajak mengunjungi beberapa lokasi wisata
(Lew and McKercher, 2006).

Secara tidak langsung operator wisata juga berpotensi merusak terumbu karang, seperti penambatan perahu pada karang massive dikarenakan banyaknya perahu yang beroperasi secara bersamaan melebihi kapasitas mooring buoy, pemilihan area pada spot wisata yang dapat dijangkau oleh fins wiasatawan, serta operator yang bersifat pasif atau tidak menegur terhadap perilaku wisatawan yang berpotensi merusak terumbu karang, bahkan turut serta menginjak karang pada saat melaksanakan foto bawah air dan pengawasan wisatawan. Pemberian pakan ikan oleh wisatawan yang difasilitasi oleh operator wisata bisa berdampak positif maupun negatif seperti perubahan ke-

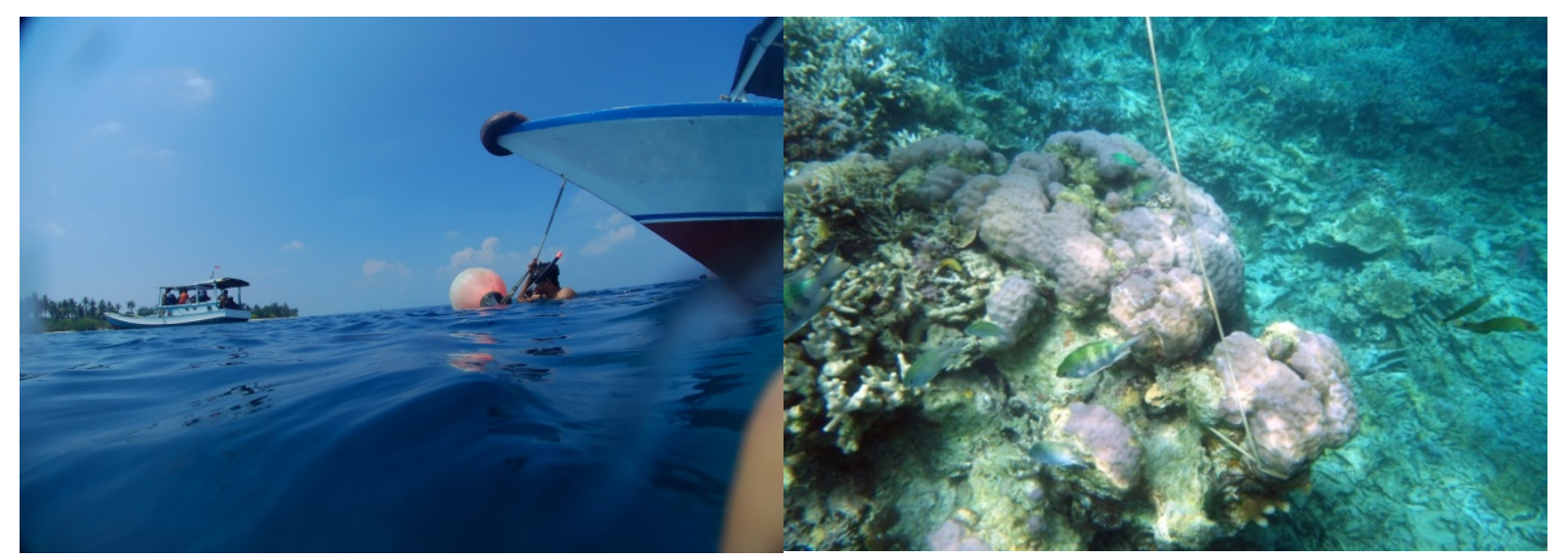

a

b

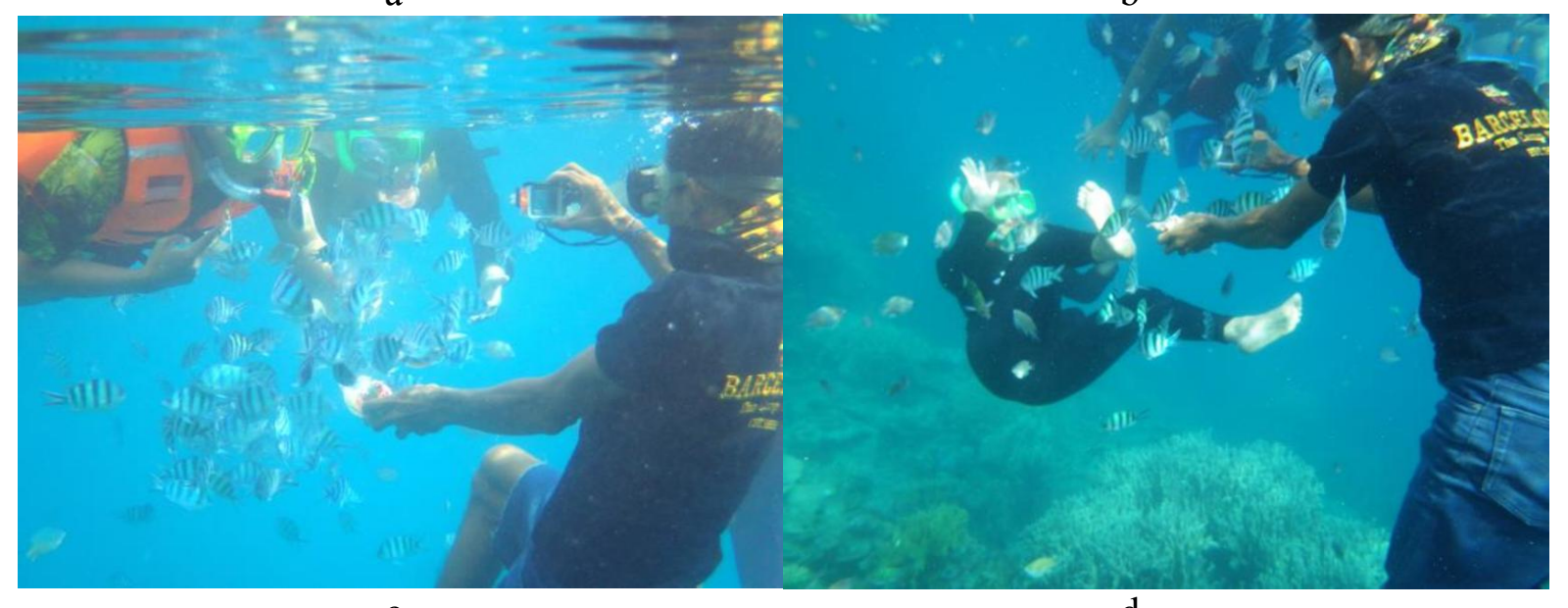

C

d

Gambar 7. Kontak fisik operator wisata. Penambatan perahu pada karang (a), Mooring Buoy pada spot snorkeling (b), Kegiatan foto yang dilakukan oleh operator wisata sebagai salah satu daya tarik wisata $(c, d)$. 
limpahan, kebiasaan dan ukuran ikan pada jenis tertentu, menarik ikan dengan agresi besar, atau membantu populasi ikan yang sedikit (Orams, 2002; Milazzo et al., 2005; Laroche et al., 2007). Perilaku ikan juga dapat berubah dalam menghadapi lingkungan yang merupakan suatu bagian dari adaptasi, atau bahkan merubah rantai makanan, dalam melakukan kegiatan wisata. Pemberian pakan pada ikan dapat memberikan kesan tersendiri bagi wisatawan, serta bagi operator wisata juga merupakan suatu upaya untuk melayani dan menarik wisatawan dengan harapan pengunjung memiliki keinginan untuk kembali mengunjungi lokasi wisata (Orams, 2002; Hémery and McClanahan, 2005; Milazzo et al, 2006).

\section{KESIMPULAN}

Berdasarkan kajian yang dilakukan pada spot snorkeling di destinasi wisata Taman Nasional Karimunjawa dapat ditarik kesimpulan, bahwa kontak fisik terhadap terumbu karang yang paling sering dilakukan wisatawan snorkeling pada ketiga spot wisata adalah duduk-berdiri-berlutut (sit-standkneel), sedangkan kontak fisik oleh operator wisata pada ketiga spot wisata snorkeling terjadi karena penambatan perahu pada terumbu karang serta pemberian pakan pada ikan. Kerusakan koloni karang pada spot wisata berupa kematian koloni secara parsial, permukaan koloni karang yang terkikis serta cabang yang patah. Kedalaman terumbu karang yang dangkal atau dapat dijangkau oleh fins wisatawan dapat meningkatkan ancaman kontak fisik wisatawan terhadap terumbu karang. Adanya peran penting operator wisata selama kegiatan wisata berlangsung, dimana operator wisata berhubungan langsung dengan wisatawan dan terumbu karang selama melakukan kegiatan snorkeling, diharapkan operator wisata dapat berperan aktif seperti memberikan teguran langsung kepada wisatawan, apabila berpotensi merusak terumbu karang.

\section{UCAPAN TERIMA KASIH}

Penulis mengucapkan terimakasih kepada Balai Taman Nasional Karimunjawa, Pemerintah Kabupaten Jepara, serta pihakpihak terkait yang telah memberikan dukungan fasilitas dan data dalam penelitian Potensi Kerusakan Terumbu Karang Pada Kegiatan Wisata Snorkeling di Destinasi Wisata Taman Nasional Karimunjawa.

\section{DAFTAR PUSTAKA}

Allison, W.R. 1996. Snorkeler damage to reef corals in the Maldive Islands. Coral Reefs, 15(4):215-218.

Badan Pusat Statistik Jepara (BPS-Jepara). 2014. Jepara dalam angka 2014, BPS Kabupaten Jepara, Provinsi Jawa Tengah. Jepara. 397 hlm.

Badan Pusat Statistik Jepara (BPS-Jepara). 2015. Jepara dalam angka 2015, BPS Kabupaten Jepara, Provinsi Jawa Tengah. Jepara. $396 \mathrm{hlm}$.

Badan Pusat Statistik Jepara (BPS-Jepara). 2016. Jepara dalam angka 2016, BPS Kabupaten Jepara, Provinsi Jawa Tengah. Jepara. $233 \mathrm{hlm}$.

Balai Taman Nasional Karimunjawa (BTNK). 2012. Rehabilitasi terumbu karang di Taman Nasional Karimunjawa Tahun 2012. Kementrian Kehutanan, Dirjen Perlindungan Hutan dan Konservasi Alam. Jakarta. $24 \mathrm{hlm}$.

Buckley, R. 1996. Sustainable tourism: technical issues and information needs. Annals of Tourism Research, 23(4):925-928.

Campbell, S.J., T. Kartawijaya, I. Yulianto, R. Prasetia, and J. Clifton. 2013. Comanagement approaches and incentives improve management effecttiveness in the Karimunjawa National Park, Indonesia. Marine Policy, 41: 72-79.

Chabanet, P., M. Adjeroud, S. Andréfouët, Y.M. Bozec, J. Ferraris, J.A. Garcìa- 
Charton, and M. Schrimm. 2005. Human-induced physical disturbances and their indicators on coral reef habitats: a multi-scale approach. Aquatic Living Resources, 18(3):215230.

Dikou, A. and R. van Woesik. 2006. Partial colony mortality reflects coral community dynamics: a fringing reef study near a small river in Okinawa, Japan. Marine Pollution Bulletin, 52:269-280.

Done, T.J. 1992. Phase shifts in coral reef communities and their ecological significance. Hydrobiologia, 247:121132.

Fava, F., M. Ponti, A. Scinto, B. Calcinai, and C. Cerrano. 2009. Possible effects of human impacts on epibenthic communities and coral rubble features in the marine park of Bunaken (Indonesia). Estuarine Coastal and Shelf Science, 85(1):151-156.

Hawkins, J.P., C.M. Roberts, T. Van'T Hof, K. De Meyer, J. Tratalos, and C. Aldam. 1999. Effects of recreational scuba diving on caribbean coral and fish communities. Conservation Biology, 13(4):888-897.

Hawkins, J.P. and C.M. Roberts. 1992. Effects of recreational SCUBA diving on fore-reef slope communities of coral reefs. Biological Conservation, 62(3): 171-178.

Hémery. G., and T.R. McClanahan. 2005. Effect of recreational fish feeding on reef fish community composition and behaviour. Western Indian Ocean J. of Marine Science, 4(2):123-134.

Kay, A.M. and M.J. Liddle. 1989. Impact of human trampling in different zones of a coral reef flat. Environmental Management, 13(4):509-520.

Kementrian Kehutanan. 2012. Keputusan Direktorat Jenderal PHKA No: SK.28 /IV/Set-3/2012 tanggal 06 maret 2012 tentang Zonasi Taman Nasioonal Karimunjawa. 4 hlm.
Laroche, R.K., A.A. Kock, L.M. Dill, and W.H. Oosthuizen. 2007. Effects of provisioning ecotourism activity on the behaviour of white sharks carcharodon carcharias. Marine Ecology Progress Series, 338:199209.

Lasagna, R., G. Gnone, M. Taruffi, C. Morri, C.N. Bianchi, V. Parravicini, and S. Lavorano. 2014. A new synthetic index to evaluate reef coral condition. Ecological Indicators, 40:1-9.

Lew, A. and B. McKercher. 2006. Modeling tourist movements: a local destination analysis. Annals of tourism research, 33(2):403-423.

Liddle, M.J. and A.M. Kay. 1987. Resistance, survival and recovery of trampled corals on the Great Barrier Reef. Biological Conservation, 42:118.

Marion, J.L., and C.S. Rogers. 1994. The applicability of terrestrial visitor impact management strategies to the protection of coral reefs. Ocean \& coastal management, 22(2):153-163.

Milazzo, M., F. Badalamenti, T.V. Fernández, and R. Chemello. 2005. Effects of fish feeding by snorkellers on the density and size distribution of fishes in a mediterranean marine protected area. J. Marine Biology, 146(6):1213-1222.

Neil, D. 1990. Potential for coral stress due to sediment resuspension and deposition by reef walkers. Biological Conservation, 52(3):221-227.

Orams, M.B. 2002. Feeding wildlife as a tourism attraction: a review of issues and impacts. Tourism Management, 23(3):281-293.

Prior, M., R. Ormond, R. Hitchen, and C. Wormald. 1995. The impact on natural resources of activity tourism: a case study of diving in Egypt. International $J$. of Environmental Studies, 48(3-4):201-209. 
Roche, R.C., C.V. Harvey, J.J. Harvey, A.P. Kavanagh, M. Mcdonald, V.R. SteinRostaing, and J.R. Turner. 2016. Recreational diving impacts on coral reefs and the adoption of environmentally responsible practices within the scuba diving industry. Environmental Management, 58(1): 107-116.

Rouphael, A. and G.J. Inglis. 2001. "Take only photographs and leave only footprints?": an experimental study of the impacts of underwater photographers on coral reef dive sites. Biological Conservation, 100:281287.

Sulisyati, R., E. Poedjirahajoe, L.R. W. Frida, and C. Fandeli. 2014. Karakteristik terumbu Karang di Zona Pemanfaatan Wisata Taman Nasional Karimunjawa. Ilmu Kelautan, 19(3):139-148.
Tratalos, J.A. and T.J. Austin. 2001. Impacts of recreational scuba diving on coral communities of the Caribbean Island of Grand Cayman. Biological Conservation, 102(1):67-75.

Webler, T. and K. Jakubowski. 2016. Mitigating damaging behaviors of snorkelers to coral reefs in puerto rico through a pre-trip media-based intervention. Biological Conservation, 197:223-228.

Weng, C.N. 2009. Ecotourism and environmental conservation in small islands in the east coast of peninsular Malaysia. Malaysian J. of Environmental Management, 10(2):53-69.

$\begin{array}{ll}\text { Diterima } & : 30 \text { Mei } 2018 \\ \text { Direview } & : 05 \text { Juni } 2018 \\ \text { Disetujui } & : 05 \text { Juli } 2018\end{array}$


